\title{
PENGARUH DISIPLIN UNTUK MENINGKATKAN PROFESIONALISME GURU PADA MADRASAH NUURUL FALAAH KOTA BANDUNG
}

\author{
Kusnadi $^{1}$ \\ Politeknik Piksi Ganesha \\ J1. Gatot Subroto No.301, Maleer, Kec. Batununggal, \\ Kota Bandung, Jawa Barat 40274 \\ kusnadi@piksi.ac.id
}

\author{
Wilma Zuarko Adji ${ }^{2}$ \\ Politeknik Piksi Ganesha \\ J1. Gatot Subroto No.301, Maleer, Kec. \\ Batununggal, Kota Bandung, Jawa Barat 40274 \\ wilma.zuarko.adji@piksi.ac.id
}

Abstrak

Penelitian ini bertujuan untuk menganalisis faktor kedisiplinan dalam meningkatkan profesionalisme guru. Metode kualitatif dengan pendekatan eksperimen diterapkan dalam penelitian ini, hasil dari penelitian ini merupakan ringkasan ari interview peneliti kepada informan, ditemukan bahwa jumlah guru tidak dapat menampung banyaknya siswa membuat para guru sering terlambat. Ketidaksamaan tingkat profesionalitas guru juga menjadikan kedisiplinan menjadi kurang. Pembahasan dalam penelitian ini ditemukan beberapa poin (1)SDM yang berkualitas dan profesional masih kurang. (2)Minimnya booster atau peningkatan seperti seminar peningkatan kualitas guru. (3)Disiplin waktu yang masih disepelekan. (4)Munculnya generasi baru sebagai guru yang minim pengalaman. (5)Sumber dana atau penghasilan untuk guru yang kecil dan masih mengandalkan aghnia santri. Upaya yang dilakukan dalam meningkatkan kualitas guru di Madrasah Nuurul Falaah, adalah sebagai berikut: (1)Untuk mengatasi kualitas guru dengan cara melakukan pelatihan dan pendidikan secara informal melalui kegiatan seminar. (2)Sumber dana untuk meningkatkan semangat moral guru dalam mengajar.

Kata kunci: guru, disiplin, profesionalisme.

(*) Corresponding Author: abiomi18@ gmail.com $(088218667015)^{1}$, wilma.zuarko.adji@ piksi.ac.id

\section{PENDAHULUAN}

Sumber Daya Manusia merupakan sorotan yang paling tajam dalam pelaksanaan kegiatan pembelajaran di dunia pendidikan, menyangkut persiapan, jumlah, pendidikan, dan profesionalisme. Di dunia pendidikan guru menjadi faktor yang sangat diandalkan untuk meningkatkan kualitas peserta didik agar mendapatkan generasi yang berkualitas dan terbaik.

Sekolah dasar atau Madrasah ialah berupa forum pendidikan yang miliki peran memadai besar di dalam peningkatan mutu sumber kekuatan manusia. Hal ini gara-gara di Madrasah pondasi primer peningkatan mutu itu di mulai untuk dikembangkan, gara-gara santri diberikan kemahiran yang dibutuhkan untuk awalan memasuki jenjang pendidikan yang selanjutnya.

Yusutria (2017) tunjukkan bahwa guru sebagai pendidik profesional miliki gambaran yang baik di mata rakyat bersama cara bisa menyatakan kepada rakyat bahwa ia pantas untuk dijadikan sebagai panutan oleh sekelilingnya terutama oleh penduduk yang akan lihat konduite dan perbuatan guru di 
dalam kesehariannya. Profesionalisme guru jadi perhatian secara dunia, sebab guru bukan sekedar bertugas dan berperan sebagai pemberi info pengetahuan ilmu dengan teknologi, juga dapat membangun sikap dan jiwa yang bisa menetap dan bersaing di dalam jaman globalisasi.

Disiplin merupakan keliru satu kegunaan manajemen sumber kekuatan manusia di dalam aspek pendidikan yang terlalu berarti di dalam terwujudnya tujuan, gara-gara tidak terdapatnya disiplin maka bakal sulit terwujudnya cita-cita pendidikan yang optimal. Terhadap sisi lain faktor disiplin sanggup pula menaikkan kinerja guru. Heidjrachman dan Husnan di dalam Lijan Poltak Sinambela (2018 :333) disiplin ialah tiap-tiap perseorangan serta kelompok dalam menjamin adanya kepatuhan pada perintah serta berinisiatif untuk lakukan aksi yang di perlukan seandainya bukan tersedia perintah.

Kinerja ialah sebuah ukuran kesuksesan seseorang guru di dalam laksanakan pekerjaannya. Guru punyai kinerja baik sanggup dipastikan berhasil di dalam melakukan perannya sebagai seseorang guru. namun banyak kebenaran yang bisa dilihat bahwa kinerja guru kebanyakan masih terasa minim sehingga perlu ditingkatkan. Kinerja guru belum optimal karena guru melakukan pekerjanya hanya sebagai kegiatan biasa, kurang kreativitas. Rendahnya kualitas profesionalisme dan disiplin guru mempengaruhi perkembangan dalam kemampuan peserta didik, adapun unsur yang mempengaruhi kurangnya kualitas profesionalisme dan disiplin guru antara lain: sarana, organisasi tempat mengajar, kebijakan.

Kinerja guru menggambarkan kemampuan kerja guru yang tampak berasal dari performa kerja di dalam jalankan profesinya jadi guru. Sebaliknya apabila keahlian seorang guru kurang baik akan menjadi melemah. masih banyak guru yang mengabaikan profesionalisme dan disiplin terhadap tanggung jawab terhadap profesinya, oleh sebab tersebut memadai signifikan untuk lakukan kajian lebih lanjut untuk menaikkan profesionalisme dan kedisiplinan guru supaya menghasilkan kinerja guru yang maksimal dan menghasilkan peserta didik yang berkualitas.

\section{METODE}

Menurut Sugiyono $(2018 ; 213)$ metode penelitian kualitatif yakni metode penelitian berlandaskan terhadap filsafat, yang dipakai dalam meneliti terhadap konteks ilmiah (Eksperimen) yang mana peneliti sebagai instrumen, Teknik dipengumpulan informasi dan dianalisis yang mempunyai sifat kualitatif lebih menekan terhadap arti. Metodelogi penelitian kualitatif bertuju untuk menganalisa serta mendeskripsikan kenyataan ataupun obyek penelitian lewat kesibukan sosial, sikap dan pandangan orang secara individu ataupun kelompok. 
Penelitian ini menggunakan cara kualitatif yaitu penelitian yang dipakai untuk mempelajari pada keadaan obyek biasa untuk suatu gambaran secara fakta dan natural di mana penelitian ini akan menggambarkan realita dan konkret yang terjadi di Madrasah Nuurul Falaah Kota Bandung. Teknik mengumpulkan data dengan observasi, wawancara serta dokumentasi. yang perlu dilakukan di penelitian ini yakni seluruh data yang bersangkutan dengan Madrasah Nuurul Falaah Kota Bandung. Sumber informasi yang diperoleh lewat wawancara, observasi dan dokumentasi pada kepala Madrasah, staf guru, dan guru-guru di Madrasah Nuurul falaah. Penelitian ini mendapatkan data langsung melalui bagian yang berkaitan dan sebagai acuan yang relevan dalam pembahasan penelitian.

\section{HASIL DAN PEMBAHASAN}

Dari hasil wawancara dengan Kepala Madrasah diketahui bahwa kedisplinan dan profesionalisme guru di Madrasah Nuruul Falaah Kota Bandung cukup baik, hanya saja ada beberapa faktor yang bisa membuat guru di Madrasah Nuurul Falaah kadang mengabaikan kedisiplinan dan profesionalismenya. Faktor tersebut adalah yang pertama ketepatan waktu guru yang masih kadang terlambat dalam mengisi jadwal pembelajaran. Hal ini disebabkan karena jadwal yang padat yang didapat oleh para guru dalam mengisi jadwal mengajar. Jumlah santri yang tidak sepadan dengan jumlah guru yang mengajar, data didapat dari Kepala Madrasah Nuurul Falaah jumlah santri mencapai 413 orang sedangkan guru yang hanya 28 orang. Faktor ini menyebabkan kedisiplinan guru yang menurun karena jadwal yang padat.

Indikator yang kedua adalah guru yang tidak semuanya memiliki dasar profesionalisme tinggi sehingga mengabaikan kualitas mengajar yang baik, seperti halnya guru hanya menjalankan kewajibannya menjadi seorang guru dalam mengisi jadwal pembelajaran, sehingga dapat menyampingkan bagaimana cara agar murid dapat mengerti pembelajaran yang diberikan dan dapat menerapkannya atau mengaplikasikan hasil pembelajaran tersebut di kehidupan sehari-hari.

Dari hasil wawancara di atas, maka dari aspek kedisiplinan guru di Madrasah Nuurul Falaah yang kurang maksimal. Karena kedisiplinan menurut Slameto (Hamzah, F, 2020) adalah salah satu yang terpenting dan merupakan kunci dalam mencapai kesuksesan maupun keberhasilan seseorang. Sedangkan menurut Rivai (Latif, D.P.I. \&Amp; Santoso, W.B. \&Nbsp;2016) kedisiplinan merupakan faedah operatif MSDM yang sangat penting, apabila disiplin karyawan baik terhadap corporate, maka Prestasi kerja akan mudah digapai.

Menurut Wahyudi di dalam kutipan Cut Fitriani \&Amp; Usman (2017) guru profesional adalah guru yang bisa mengelola dirinya sendiri di dalam lakukan tugas-tugasnya sehari-hari. Profesionalisme 
yang dimaksud oleh mereka adalah satu proses yang bergerak berasal dari ketidaktahuan jadi paham, berasal dari ketidakmatangan jadi matang. Menurut Prof. Dr. M. Surya dkk. yang dikutip Siti Suwaibatul Aslamiyah (2016) mengartikan bahwa profesional punya makna yang mengacu kepada nama mengenai orang yang menyandang sebuah profesi dan julukan perihal penampilan seseorang di dalam mewujudkan unjuk kerja disesuaikan bersama dengan profesinya.

Berdasarkan hasil wawancara di atas, diketahui hambatan yang dipaparkan oleh Kepala Madrasah Nuurul Falaah dalam mengembangkan sistem pembelajaran yang berkualitas adalah sebagai berikut: (1)SDM yang berkualitas dan profesional masih kurang. (2)Minimnya booster atau peningkatan seperti seminar peningkatan kualitas guru. (3)Disiplin waktu yang masih disepelekan. (4)Munculnya generasi baru sebagai guru yang minim pengalaman. (5)Sumber dana atau penghasilan untuk guru yang kecil dan masih mengandalkan aghnia santri.

Upaya yang dilakukan dalam meningkatkan kualitas guru di Madrasah Nuurul Falaah, adalah sebagai berikut: (1)Untuk mengatasi kualitas guru dengan cara melakukan pelatihan dan pendidikan secara informal melalui kegiatan seminar. (2)Sumber dana untuk meningkatkan semangat moral guru dalam mengajar.

\section{PENUTUP}

Berdasarkan hasil penelitian dapat disimpulkan bahwa profesionalisme guru di Madrasah Nuurul Falaah Kota Bandung masih belum maksimal. Hal ini terbukti dari efektivitas cara mengajar guru dikarenakan tinggi di Madrasah Nuurul Falaah yang masih perlu diupgrade atau ditingkatkan. Dikarenakan beban keranjang sangat tinggi, rasio guru terhadap murid masih kurang, minimnya pengalaman para guru.

Hambatan yang terjadi dan upaya yang dilakukan di Madrasah Nuurul Falaah Kota Bandung seperti halnya kualitas disiplin dan profesionalisme guru yang masih kurang dari mulai efektivitas waktu dalam pembelajaran yang bisa dilakukan dengan cara membuat seminar atau pelatihan khusus demi meningkatkan kualitas guru dalam mengajar terlebih regenerasi atau guru-guru muda yang minim pengalaman agar terlatih dan mapan untuk menjadi seorang guru yang profesional. Sumber dana yang masih mengandalkan infaq aghnia yang tidak besar jumlahnya menjadi penilaian lainnya demi meningkatkan semangat mengajar demi tercapainya profesionalisme dari seorang guru.

\section{DAFTAR PUSTAKA}


Aslamiyah, S. \& Lamongan, F. A. I. U. I. (2016). Profesionalisme Guru dalam Perspektif Islam. Jurnal Akademika, 10(2), 180.

Fitriani. A.,\& Usman, N. (2017). Kompetensi Profesional Guru dalam Mengelola Pendidikan di MTs Muhammadiyah Banda Aceh. Jurnal Administrasi Pendidikan: Program Pascasarjana Unsyiah, 5(2).

Hamzah, F. (2020). HUBUNGAN ANTARA PENGARUH TEMAN SEBAYA TERHADAP DISIPLIN BELAJAR. SPEKTRUM: Jurnal Pembelajaran Luar Sekolah( PLS), 8(3), 301308.

Rahardi, M. T. P., \& Setiawan, H. H. (2019). PENGARUH STRES KERJA dan KEDISIPLINAN TERHADAP KINERJA KARYAWAN DI GH UNIVERSAL HOTEL (Doctoral dissertation, Perpustakaan Fakultas Ekonomi dan Bisnis Unpas).

Sopian, A. (2016). Tugas, Peran, serta Fungsi Guru dalam Pendidikan. Raudhah Proud To Be Professional, 1(1), 88- 97.

Sugiyono. (2018). Metode Penelitian Kuantitatif, Kualitatif, dan R\&D. Bandung: Alfabeta.

Yusutria. A. (2017). Profesionalisme Guru dalam Tingkatkan Kualitas Sumber Daya Manusia. Curriculla: Journal of Teaching and Learning, 2(1). 